\title{
ДОВІЧНА ПРОДУКТИВНІСТЬ КОРІВ УКРАЇНСЬКОЇ ЧЕРВОНО-РЯБОЇ МОЛОЧНОЇ ПОРОДИ ЗА РІЗНИХ ВАРІАНТІВ ПІДБОРУ
}

\author{
Хмельничий Леонтій Михайлович \\ доктор сільськогосподарських наук, профресор \\ Сумський національний аграрний університет \\ ORCID: 0000-0001-5175-1291 \\ E-mail:khmelnychy@ukr.net
}

Супрун Ірина Олександрівна кандидат сільськогосподарських наук, доцент Національний університет біоресурсів і природокористування України ORCID: 0000-0001-8105-1923 E-mail: isuprun@nubip.edu.ua

Бардаш Дмитрій Олександрович аспірант спеціальності 204-ТВППТ

Сумський національний аграрний університет

ORCID: 0000-0002-9368-2324

Email: d.bardash@ukr.net

\begin{abstract}
Наведено результати досліджень корів української червоно-рябої молочної породи за ознаками тривалості господарського використання та довічної продуктивності у межах оцінки генеалогічних формувань. Експериментальною базою проведених досліджень служила ретроспективна селекиійна інфоормація стада підприємства ТОВ «Млинівський комплекс» Роменської філії Сумської області. Оиінку показників тривалості та ефективності довічного використання проводили за методикою Ю.П. Полупана (2010), заффіксувавши по кожній досліджуваній корові інфрормацію про дати народження, першого отелення і вибуття. По кожній лактації враховували ії тривалість, надій, вміст та вихід молочного жиру за усю лактацію. Вивчали спадковий вплив генеалогічних формувань на показники тривалості господарського використання та довічної продуктивності при внутрішньолінійному підборі та в окремих варіантах міжлінійних поєднань. За результатами оцінки потомства корів, одержаних при внутрішньолінійному підборі п'яти генеалогічних форммувань підконтрольного стада, встановлено достовірний вплив спадковості ліній на показники довічної продуктивності. Виявлені в окремих варіантах внутрішньолінійного і міжлінійного підбору вдалі та невдалі поєднання свідчать про необхідність проведення у заводських стадах системної оцінки при підборі бугаїв-плідників відповідних генеалогічних формувань. Повторне застосування найбільш ефективних варіантів та відмова від невдалих буде сприяти нарощуванню генетичного потенціалу продуктивності молочної худоби.
\end{abstract}

Ключові слова: українська червоно-ряба молочна порода, лінія, довічна продуктивність.

DOI: https://doi.org/10.32845/bsnau.lvst.2021.1.4

Економічна ефеективність ведення галузі молочного скотарства значним чином залежить від генетичного потенціалу корів, тривалості продуктивного використання та рівня показників довічної продуктивності $[17,30]$. Ознаки, які характеризують довічну продуктивність корів молочної худоби, як і будь які інші кількісні ознаки, мають полігенне успадкування, відрізняються низькою успадковуваністю [15], хоча ніхто не сумнівається в їхній суворій спадковій обумовленоcri.

Про те, що низька успадковуваність обмежує можливості масової селекції підтверджують зарубіжні наукові джерела. За даними досліджень багатьох авторів ступінь мінливості успадковуваності тривалості життя склала 0,01-0,36 залежно від породи і методу дослідження [32]. Іншими джерелами інформації повідомляється, що успадковуваність тривалості життя корів голштинської породи варіювала від 0,05 до 0,07 [33], у тварин симентальської породи Чехії вони перебували в діапазоні від 0,04 до 0,05 [35], а голштинської - від 0,03 до 0,05 [34]. Про генетичну складову в загальній фенотиповій мінливості ознак продуктивного довголіття повідомляється і у вітчизняних дослідженнях $[18,28,29]$.

Одна із біологічних особливостей великої рогатої ху-

доби полягає у тому, що за умови раціональних методів утримання та повноцінної годівлі, корови здатні зберігати високий рівень продуктивності та відтворну здатність до 1012-ти річного віку. Однак, нарощування продуктивних та поліпшення технологічних якостей тварин нечасто супроводжується підвищеною вибагливістю до умов вирощування, годівлі, утримання і, як наслідок, призводить до зниження ознак продуктивного довголіття. Ю.П. Полупан [16] вважає, що це зумовлено природним антагонізмом, зворотною співвідносною мінливістю між молочною продуктивністю і тривалістю господарського використання.

Довголітнє використання корів крім економічної складової, особливого значення набуває при веденні селекційно-племінної роботи, оскільки тривалість господарського використання тісно пов'язана з темпами ремонту стада, а значить і з інтенсивністю добору. Передчасне вибраковування корів не лише скорочує племінні ресурси порід, але й завдає економічного збитку галузі в цілому, оскільки витрати на вирощування високопродуктивних корів починають окупатися лише після третього отелення. Якщо середня тривалість використання маточного поголів'я буде становити менше за 2,5 лактації, тоді матері почнуть вибувати із стада 
раніше, ніж їхні дочки дадуть потомство. За такого становища стадо перестане існувати як цілісна біологічна система і станеться її розпад [22].

Не дивлячись на те, що розвиток будь якої господарськи корисної ознаки за низької успадковуваності істотно залежить від паратипових чинників, за даними окремих дослідників показники тривалості продуктивного використання корів детермінуються генотипом тварин, зокрема їхньою належністю до породи та лінії [1, 10, 11, 14, 31]. Спадковий вплив генеалогічних формувань на показники ознак довголіття корів української червоно-рябої молочної породи встановлено у стаді племінного заводу АФ «Маяк» Золотоніського району Черкаської області [24], ПСП ПЗ "Пісківське" Бахмацького району Чернігівської області [26, 27]

Українська червоно-ряба молочна порода - одна з кращих вітчизняних порід, яка поширена майже у всіх регіонах України. У даний час на спадковість породи чинить вплив світовий генофонд голштинських бугаїв-плідників різного генеалогічного походження. Прогрес породи та її конкурентоспроможність визначатиметься не лише наявністю високопродуктивних корів з міцною конституцією, стійких до захворювань, придатних до машинного доїння, але й показниками довічної продуктивності. Тому вивчення особливостей української червоно-рябої молочної породи за довічними продуктивними якостями залежно від генеалогічних формувань $€$ наразі вмотивованим та актуальним напрямом досліджень.

Матеріали та методи досліджень. Експериментальною базою проведених досліджень служила ретроспективна селекційна інформація стада підприємства ТОВ «Млинівський комплекс» Роменської філії Сумської області 3 розведення української червоно-рябої молочної породи.

Оцінку показників тривалості та ефективності довічного використання проводили за методикою Ю.П. Полупана [16], зафріксувавши по кожній досліджуваній корові інформацію про дати народження (Дн), першого отелення (Д1от) і вибуття (Дв). По кожній лактації (i = n) враховували її тривалість (Тлі), надій (Нi), вміст (\%Жд) та вихід молочного жиру (МЖі) за усю лактацію. Показники тривалості та селекційної ефективності довічного використання корів обчислювали за наступними формулами:

- тривалість господарського використання (днів) Тгв =Дв - Д10Т;

- довічний надій (кг) - Нд $=\Sigma \mathrm{Hi}$;

- довічний вихід молочного жиру (кг) - МЖд = $\sum$ МЖі;

- середній довічний вміст жиру в молоці (\%) $\%$

- середній надій на 1 день господарського використання (кг) - Ндгв $=$ Нд / Тгв;

- кількість використаних лактацій (шт.) - Квл = $\sum$ Квл

Біометричне опрацювання результатів досліджень проводили за формулами, наведеними Е.К. Меркурьевой [13] на ПК з використанням програмного забезпечення у середовищі Microsoft Excel.

Результати досліджень. У науковій літературі неодноразово повідомлялося про ефективність як внутрішньолінійного розведення, так і кросу ліній. Про селекційну користь внутрішньолінійного розведення свідчить довготривала практика зоотехнії. Структуризація породи на окремі лінії, які відрізняються за розвитком господарськи корисних ознак, тобто спадково контролюються відповідно різними генотипами, дозволяє створити у їхніх межах тварин з досить високою спадковою стійкістю, обумовленою великою кількістю генів, що сприяють як розвитку господарськи корисних ознак, так і зростанню гомозиготності до того рівня, який не викликає інбредної депресії, зберігаючи у породі достатній рівень мінливості [4]. Крім того, при удосконаленні порід і типів молочної худоби не можливо сконцентрувати в одній тварині усі цінні якості, якими характеризується порода. Тому упродовж селекційного процесу в окремих лініях накопичуються різні позитивні господарськи корисні ознаки із яких складається структура породи, надаючи їй пластичність, необхідну для подальшого її поліпшення. У процесі подальшого свого розвитку лінія, окрім поширення спадкових ознак родоначальника, утримує і об'єднує з ним позитивні якості інших тварин. При цьому відбувається перетворення цінних властивостей у групові не одного родоначальника, а й кращих маток, з якими він спаровується. Цей процес приводить до прогресу лінії, основною властивістю якої $€$ здатність у кожному наступному поколінні давати плідників, які за своїми якостями не поступаються родоначальникам. Тому внутрішньолінійне розведення повинно забезпечувати генетичний прогрес, але за умови чіткого дотримання системи добору, підбору та оцінки тварин за племінною цінністю. Вважається, що ефективність лінійного розведення залежить від числа поколінь її продовжувачів та наявності у ній бугаїв-лідерів, щоб забезпечити упродовж чотирьохшести поколінь їхній прогресивний розвиток [2, 3, 5, 9, 21]

3 іншого боку, існує теоретичне підґрунтя, яке свідчить, що крос генеалогічних формувань, навпаки, завдяки зростанню гетерозиготності призводить до підвищення показників життєздатності, відтворення та продуктивності у потомства $[6,8,12,19,20]$. Існують також окремі наукові дослідження, які свідчать, що не кожний міжлінійний підбір дозволяє отримати кращі результати [7, 23, 25], тому у практичній селекційно-племінній роботі зі стадом необхідно відшуковувати вдалі міжлінійні поєднання, оскільки безсистемне схрещування ліній не завжди сприяє консолідації окремих ознак і замість очікуваного бажаного ефекту призводить до погіршення показників продуктивності.

Враховуючи важливий селекційний аспект заходу стосовно внутрішньо- та міжлінійного розведення вважаємо за доцільне дослідити ефективність поєднання ліній при розведенні української червоно-рябої молочної породи підконтрольного стада за ознаками тривалості використання та довічної продуктивності (таблиця).

Узагальнюючи результати оцінки потомства корів, одержаних при внутрішньолінійному підборі п'яти генеалогічних формувань підконтрольного стада, встановлено достовірний вплив спадковості ліній на показники довічної продуктивності. У ранзі за оцінкою ознаки тривалості господарського використання першу позицію зайняло потомство корів відомої у голштинській та українській червоно-рябій молочній породі генеалогічної лінії Хеневе 1629391 з надоєм яке, на підтвердження свого спадкового впливу з достовірною різницею на 259-487 днів $(P<0,05-0,001)$ перевершувало потомство решти ліній.

Генеалогічні формування Хеневе 1629391 та Інгансе 343514 - це заводські лінії в українській червоно-рябій молочній породі, потомство яких зайняло у рейтингу оцінки за ознакою тривалості господарського використання відповідно 
першу (2814 днів) та другу (2555 днів) позиції.

Таблиця

Тривалість використання та довічна продуктивність корів при внутрішньолінійному та міжлінійному підборах

\begin{tabular}{|c|c|c|c|c|c|c|c|c|}
\hline \multicolumn{2}{|c|}{ Лінія } & \multirow[t]{2}{*}{$\mathrm{n}$} & \multicolumn{2}{|c|}{ Тривалість використання } & \multicolumn{4}{|c|}{ Молочна продуктивність } \\
\hline батька & матері & & $\begin{array}{c}\text { господарського, } \\
\text { дн. }\end{array}$ & лактацій, шт & $\begin{array}{l}\text { довічний } \\
\text { надій, кг }\end{array}$ & $\begin{array}{c}\text { довічний вміст } \\
\text { жиру, \% }\end{array}$ & $\begin{array}{l}\text { довічний вихід } \\
\text { жиру, кг }\end{array}$ & $\begin{array}{c}\text { надій на один день } \\
\text { господарського } \\
\text { використання, кг }\end{array}$ \\
\hline \multirow{4}{*}{$\begin{array}{l}\text { Інгансе } \\
343514\end{array}$} & Інгансе & 33 & $2555 \pm 89,5$ & $4,6 \pm 0,19$ & $32859 \pm 921,4$ & $3,78 \pm 0,015$ & $1246 \pm 33,1$ & $12,9 \pm 0,41$ \\
\hline & Хеневе & 22 & $2730 \pm 98,6$ & $4,9 \pm 0,28$ & $39911 \pm 979,2$ & $3,80 \pm 0,013$ & $1516 \pm 41,5$ & $14,6 \pm 0,49$ \\
\hline & Кевеліе & 39 & $2622 \pm 74,2$ & $4,8 \pm 0,21$ & $33118 \pm 735,5$ & $3,77 \pm 0,014$ & $1249 \pm 25,6$ & $12,6 \pm 0,28$ \\
\hline & П.Ф.А. Чіфа & 21 & $1881 \pm 92,7$ & $2,7 \pm 0,33$ & $15747 \pm 992,9$ & $3,78 \pm 0,013$ & $595,2 \pm 38,5$ & $8,4 \pm 0,63$ \\
\hline \multirow{3}{*}{$\begin{array}{c}\text { Р. Сітейшна } \\
267150\end{array}$} & Р. Сітейшна & 24 & $2552 \pm 87,4$ & $3,9 \pm 0,28$ & $23265 \pm 857,3$ & $3,74 \pm 0,015$ & $870,1 \pm 37,6$ & $9,1 \pm 0,65$ \\
\hline & С.Т. Рокіта & 23 & $2451 \pm 91,7$ & $4,3 \pm 0,26$ & $21009 \pm 925,4$ & $3,80 \pm 0,019$ & $798,3 \pm 33,7$ & $8,6 \pm 0,51$ \\
\hline & Р. Совріна & 27 & $2324 \pm 85,3$ & $4,1 \pm 0,39$ & $22332 \pm 955,6$ & $3,76 \pm 0,017$ & $839,7 \pm 27,3$ & $9,6 \pm 0,40$ \\
\hline \multirow{4}{*}{$\begin{array}{l}\text { Р. Совріна } \\
0198998\end{array}$} & Р. Совріна & 29 & $2327 \pm 88,3$ & $3,8 \pm 0,34$ & $20244 \pm 873,1$ & $3,85 \pm 0,014$ & $779,4 \pm 29,8$ & $8,7 \pm 0,33$ \\
\hline & Хеневе & 47 & $2779 \pm 71,8$ & $4,9 \pm 0,25$ & $27951 \pm 652,7$ & $3,78 \pm 0,010$ & $1057 \pm 25,7$ & $10,1 \pm 0,27$ \\
\hline & Валіанта & 26 & $2447 \pm 86,3$ & $4,2 \pm 0,21$ & $22537 \pm 954,3$ & $3,79 \pm 0,013$ & $854,2 \pm 33,2$ & $9,2 \pm 0,35$ \\
\hline & С.Т. Рокіта & 36 & $2245 \pm 74,5$ & $4,3 \pm 0,22$ & $24652 \pm 725,4$ & $3,78 \pm 0,011$ & $931,8 \pm 27,8$ & $11,0 \pm 0,28$ \\
\hline \multirow{4}{*}{$\begin{array}{c}\text { Хеневе } \\
1629391\end{array}$} & Хеневе & 28 & $2814 \pm 92,3$ & $5,3 \pm 0,44$ & $32474 \pm 814,3$ & $3,79 \pm 0,013$ & $1231 \pm 35,6$ & $11,5 \pm 0,56$ \\
\hline & Р. Совріна & 33 & $2112 \pm 93,4$ & $3,4 \pm 0,47$ & $19894 \pm 745,8$ & $3,83 \pm 0,010$ & $761,9 \pm 33,9$ & $9,4 \pm 0,46$ \\
\hline & Валіанта & 37 & $2191 \pm 78,3$ & $3,8 \pm 0,32$ & $18612 \pm 808,1$ & $3,74 \pm 0,012$ & $696,1 \pm 27,4$ & $8,5 \pm 0,44$ \\
\hline & Р. Сітейшна & 22 & $1928 \pm 97,7$ & $2,8 \pm 0,41$ & $15685 \pm 928,4$ & $3,78 \pm 0,012$ & $592,9 \pm 44,2$ & $8,1 \pm 0,52$ \\
\hline \multirow{3}{*}{$\begin{array}{c}\text { Валіанта } \\
1650414\end{array}$} & Валіанта & 21 & $2333 \pm 88,3$ & $4,1 \pm 0,48$ & $24655 \pm 945,8$ & $3,78 \pm 0,014$ & $931,9 \pm 38,5$ & $10,6 \pm 0,46$ \\
\hline & Хеневе & 39 & $2833 \pm 84,1$ & $5,2 \pm 0,22$ & $35248 \pm 686,2$ & $3,82 \pm 0,017$ & $1347 \pm 27,9$ & $12,4 \pm 0,25$ \\
\hline & Кевеліе & 32 & $2811 \pm 94,7$ & $5,1 \pm 0,23$ & $33427 \pm 708,3$ & $3,83 \pm 0,014$ & $1280 \pm 31,7$ & $11,8 \pm 0,26$ \\
\hline
\end{tabular}

Нащадки лінії Хеневе 1629391 відрізнялися також найвищою тривалістю використання лактацій $(5,3) 3$ перевищенням потомства чотирьох ліній (Інгансе, Р. Сітейшна, Р. Совріна, Валіанта) на 0,7-1,5 лактацій з достовірністю при $\mathrm{P}<0,01$ лише у порівнянні з лінією $\mathrm{P}$. Совріна.

Найголовніша із ознак, яка характеризує довічну продуктивність - довічний надій корів. За цією ознакою акценти у потомства, отриманого від внутрішньолінійного розведення, у рейтингу щодо першості дещо змістилися. Першу позицію зайняли корови, що належали заводській лінії Інгансе з довічним надоєм 32859 кг молока, другу - 3 незначною різницею, нащадки наступної заводської лінії Хеневе (32474 кг) і лише третю, зайняли нащадки також заводської лінії Валіанта (24655 кг). За довічним надоєм корови заводської лінії Інгансе з достовірною різницею перевищували потомство решти оцінюваних ліній з різницею від 8204 ( $\mathrm{P}<0,001$; лінія Валіанта) до 12615 ( $\mathrm{P}<0,001$; лінія Р.Совріна).

Мінливість вмісту жиру в молоці корів оцінюваних ліній варіювала у межах 3,74-3,85\%, при цьому міжлінійна різниця в 1,1\% має високу достовірність ( $\mathrm{P}<0,001)$.

За оцінкою довічного виходу молочного жиру кращими були нащадки ліні Хеневе та Інгансе. Вони при середньому значенні показника відповідно 1246 та 1231 кг перевищували корів решти генеалогічних формувань з різним рівнем достовірності, від 299,1 кг ( $\mathrm{P}<0,001$; лінія Валіата) до 466,6 кг ( $\mathrm{P}<0,001$; лінія Р.Совріна).

Показник надою на один день життя також був вищий у потомства бугаїв лінії Інгансе і становив 12,9 кг. Достовірна різниця виявлена у всіх порівняннях від 1,4 кг (лінія Хеневе; $P<0,05)$ до 4,2 кг (лінія Р.Совріна; $P<0,001$ ).

Аналіз міжлінійного підбору у різних варіантах поєднань батьківських та материнських ліній показав істотну мінливість потомства, отриманого від цих варіантів, за оцінюваними ознаками тривалості господарського використання та довічної молочної продуктивності.
Використання бугаїв-плідників батьківської лінії Валіанта виявилося найбільш вдалим у міжлінійному кросі 3 бугаями материнських заводських ліній Хеневе та Кевеліе, ніж при внутрішньолінійному підборі з лінійними плідниками. Корови, отримані у варіантах кросів ліній Валіанта × Хеневе та Валіанта $\times$ Кевеліе, виявились кращими у порівнянні 3 тваринами, отриманими від внутрішньолінійного підбору, за тривалістю господарського використання 3 достовірною різницею відповідно на 500 та 478 днів $(\mathrm{P}<0,001)$, кількістю використаних лактацій - 1,0 та $1,1(\mathrm{P}<0,05)$, довічним надо$\epsilon \mathrm{\epsilon}-10593$ та 8772 кг ( $\mathrm{P}<0,001)$, за виходом молочного жиру - 415,1 та 348,1 кг і за надоєм на один день господарського використання - 1,8 $(\mathrm{P}<0,001)$ та 1,2 кг $(\mathrm{P}<0,05)$.

Аналіз результатів з розведення тварин за використання внутрішньолінійного підбору у підконтрольному стаді виявив кращий результат в порівнянні з лінійними кросами лише у варіанті Хеневе $\times$ Хеневе. За тривалістю господарського використання (2814 днів) корови від цього підбору були кращими у порівнянні 3 потомками, отриманими від невдалого поєднання кросів плідників батьківської ліній Хеневе з коровами від бугаїв материнських ліній Р Совріна, Валіанта та Р. Сітейшна, на 623-886 днів $(P<0,001)$, кількістю використаних лактацій - 1,5-2,5 штук $(P<0,05-0,001)$, довічним надоєм - 12580-16789 кг ( $\mathrm{P}<0,001)$, довічним виходом молочного жиру - 469,1-638,1 кг $(\mathrm{P}<0,001)$ та за надоєм на один день господарського використання - 2,1-3,4 кг $(\mathrm{P}<0,01-0,001)$.

Розгляд дочірнього потомства, отриманого від використання плідників батьківської лінії Інгансе у внутрішньолінійному підборі та міжлінійних кросах з плідниками материнських ліній Хеневе, Кевеліе та Чіфа, засвідчив про кращі результати щодо тривалості використання та довічної продуктивності у корів від кросів ліній Інгансе хХеневе та Інгансе $\times$ Кевеліе. Серед них найкращим виявився міжлінійний підбір бугаїв Інгансе $\times$ Хеневе. Потомство від цього підбору перевищувало усі інші варіанти 3 використанням бугаїв 
батьківської лінії Інгансе за тривалістю господарського використання на 108-849 днів, кількістю лактацій - 0,1-2,2 шт., довічним надоєм - 6793-24164 кг, довічним виходом молочного жиру - 266-919,8 та надоєм на один день господарського використання - 1,7-6,2 кг. Різниця, за виключенням мінімального значення, достовірна 3 мінливістю у межах $P<0,05-0,001$.

Результати оцінки дочірнього потомства, отриманого від бугаїв-плідників батьківської ліній Р. Сітейшна, за використання їх як у внутрішньолінійному, так і міжлінійному підборах, засвідчили незначну мінливість за тривалістю господарського використання. Різниця за цією ознакою між крайніми варіантами потомства від поєднання ліній Р. Сітейшна × Р. Сітейшна та Р. Сітейшна $\times$ Р. Совріна, яка склала 228 днів, виявилася недостовірною. Порівняння материнських ліній між собою за ознаками довічної молочної продуктивності також мають недостовірну різницю.

При використанні бугаїв- генеалогічної лінії Р. Совріна у різних варіантах підбору найбільш вдалим за ознаками довічної продуктивності виявився крос з плідниками материнської заводської лінії в українській червоно-рябій молочній породі Хеневе. Потомство від цього поєднання перевищувало з достовірною різницею тварин двох інших кросованих варіантів за тривалістю господарського використання на $332(\mathrm{P}<0,01)$ та 534 дні $(\mathrm{P}<0,001)$, за довічним надоєм - на 3299 та 5414 кг ( $<<0,001)$, молочним жиром на 125,2 та 202,8 кг $(P<0,001)$. Внутрішньолінійний підбір лінії Р. Совріна виявився невдалим.

Варто звернути увагу на те, що корови отримані в усіх варіантах міжлінійного підбору батьківських ліній Інгансе, Р. Совріна та Валіанта з бугаями материнської Хеневе завжди відрізнялися найвищими показниками тривалості господарського використання та довічної молочної продуктивності.

Висновки. Достовірна мінливість показників довічної продуктивності під впливом генеалогічних формувань підтверджує доцільність лінійного розведення у селекційноплемінній роботі як з даним стадом, так і з породою у ціломy.

Виявлені в окремих варіантах внутрішньолінійного і міжлінійного підбору вдалі та невдалі поєднання свідчать про необхідність проведення у заводських стадах системної оцінки при підборі бугаїв-плідників відповідних генеалогічних формувань. Повторне застосування найбільш ефективних варіантів та відмова від невдалих буде сприяти нарощуванню генетичного потенціалу продуктивності молочної худоби.

\section{Список використаної літератури:}

1. Бабік Н. П., Федорович Є. І. Продуктивне довголіття корів молочних порід за різної їх лінійної належності. Науковотехнічний бюлетень IT НАAН, 2017. №118, С.48-57.

2. Бойко Ю. М. Перспектива селекції худоби української бурої молочної породи в аспекті лінійного розведення з врахуванням світових тенденцій тривалості ліній у поколіннях. Вісник Сумського НАУ. Серія «Тваринництво». 2013. Вип. 1 (22). C. $20-26$.

3. Буркат В. П., Ладика В. І. До питання створення молочного типу бурої худоби. Удосконалення племінних і продуктивних якостей популяції бурої худоби. Матеріали науково-виробничої конференції 25-27 червня 1996 року. К.: Асоціація "Україна", 1996. С. 3-5.

4. Буркат В. П., Полупан Ю. П. Розведення тварин за лініями: генезис понять і методів та сучасний селекційний контекст. К. : Аграрна наука, 2004. 68 с.

5. Вінничук Д. Т., Стрекозов Н., Амбрампальский Ф., Абылкасымов Д. Структура породи великої рогатої худоби. Вісник сільськогосподарської науки. 1982. № 8. С. 33-38.

6. Воронина Е. Влияние вариантов подбора коров на их молочную продуктивность. Молочное и мясное скотоводство. 2007. №4. C. 8-10.

7. Ганчев М. М., Бойко М. Ф., Нарожний П. А. Виявлення поєднуваності ліній червоної степової худоби при кросах. Вісник сільськогосподарської науки. 1987. № 3. С. 27-28.

8. Гончаренко І. В. Тривалість господарського використання молочних корів як ознака селекції. Вісник аграрної науки. 2004. №6. C. 33-36.

9. Зубец М. В., Буркат В. П., Мельник Ю. Ф. [и др.]. Генетика, селекция и биотехнология в скотоводстве / под ред. М. В. Зубца, В. П. Бурката. К.: "БМТ", 1997.722 с.

10. Казанцева Е. С. Показатели продуктивного долголетия коров черно-пестрой породы в зависимости от линейной принадлежности. Аграрный вестник Урала. 2015. № 6 (136). С. 51-53.

11. Кальчук Л. А., Пелехатий М. С. Зв'язок молочної продуктивності з показниками відтворної здатності та господарського використання у корів чорно-рябої породи. Науково-технічний бюлетень. Харків. 2001. №б 80. С. 64-67.

12. Кононенко С. И., Шостак В. А., Кононенко С. И. Разведение и совершенствование животных нового регионального типа красного молочного скота. Розведення і генетика тварин. К. 2012. Вип. 46. С. 24-25.

13. Меркурьева Е. К. Генетические основы селекции в скотоводстве. М.: Колос, 1977. 240 с.

14. Моисеев К. А., Павлова Т. В., Казаровец Н. В. Влияние генотипических факторов на принадлежность хозяйственного использования и пожизненную молочную продуктивность коров в стаде РУП "Учхоз БГСХА". Розведення і генетика тварин. К. 2012. Вип. 46. С. 106-109.

15. Пащенко С. В. Повышение эфффективности селекции молочного скота на продуктивное долголетие. Нива Поволжья. 2010. № 1, С. 83-86.

16. Полупан Ю.П. Методика оцінки селекційної ефективності довічного використання корів молочних порід. Методологія наукових досліджень з питань селекції, генетики та біотехнології у тваринництві. Матеріали науково-теоретичної конференції, присвяченої пам'яті академіка УААН Валерія Петровича Бурката (Чубинське, 25 лютого 2010 року). К. : Аграрна наука, 2010. С. 93-95. 
17. Полупан Ю., Мащенко Р., Розмаріца Н., Левченко Л., Молдованова О. Молочна худоба Миколаївщини. Тваринництво України. 2007. № 6. С.17-21.

18. Полупан, Ю.П. Генетична детермінація тривалості та ефективності довічного використання чорно-рябої молочної худоби. Розведення і генетика тварин. Міжвідомчий тематичний науковий збірник. К.: 2015. Вип. 49. С. 120-133.

19. Попов Н., Уливанова Г., Ахмедова Т. Генетическая и генеалогическая однородность стад черно-пестрой породы. Молочное и мясное скотоводство. 2002. № 4 С. 22-24.

20. Сакса Е. И., Борсукова О. Е. Эффективность инбридинга при выведении коров в высокопродуктивном стаде. Зоотехния. 2010. № 2. С. 2-4.

21. Ставецька Р. В., Рудик І. А. Динаміка розвитку ліній молочної худоби. Збірник наукових праць. Серія "Технологія виробництва і переробки продукції тваринництва". Кам'янець-Подільський, 2010. Вип. 18. С.197-200.

22. Хмельничий Л. М. Проблема ефективного довголіття та довічної продуктивності молочних корів в аспекті їхньої залежності від спадкових та паратипових чинників. Вісник Сумського національного аграрного університету. Серія «Тваринництво». 2016. Вип. 7 (30). С. 13-31.

23. Хмельничий Л. М., Вечорка В. В. Ефективність внутрішньолінійного розведення та поєднуваності ліній в селекції голштинської худоби. Вісник Сумського НАУ. Серія “Тваринництво” 2010. Вип. 12 (18). С. 149-153.

24. Хмельничий Л. М., Вечорка В. В. Ефективність впливу генеалогічних формувань на показники довголіття та довічної продуктивності корів української червоно-рябої молочної породи. Вісник Сумського НАУ. Серія «Тваринництво». 2016. Вип. 1 (29). С. 3-10.

25. Хмельничий Л. М., Салогуб А. М. Ефективність поєднання генеалогічних формувань в селекції молочної худоби. Збірник наукових праць Подільського держ. аграрно-технічного університету. Серія "Технологія виробництва і переробки продукції тваринництва". Кам'янець-Подільський. 2012. Вип. 20. С. 285-287.

26. Хмельничий Л. М., Салогуб А. М., Бондарчук В. М., Лобода В. П. Показники довічної продуктивності корів української червоно-рябої молочної породи залежно від методів підбору. Таврійський науковий вісник: Науковий журнал. Херсон: Грінь Д.С. 2015. Вип. 93. С. 191-196.

27. Хмельничий Л. М., Салогуб А. М., Бондарчук В. М., Лобода В. П. Тривалість використання та довічна продуктивність корів залежно від методів підбору та бугаїв-плідників української червоно-рябої молочної породи. Вісник Сумського НАУ. Серія «Тваринництво». 2015. Вип. 6 (28). С. 65-70.

28. Хмельничий Л. М., Лобода В. П. Оценка влияния наследственных факторов на показатели пожизненной продуктивности коров украинской красно-пестрой молочной породы. Актуальные проблемы интенсивного развития животноводства: сборник научных трудов Белорусской гос. сельхоз. академии Горки: БГСХА. 2014. Вып. 17. Ч. 2. С. 159-165.

29. Хмельничий Л. М., Лобода В. П. Удосконалення стада з розведення української червоно-рябої молочної породи за показниками довічної продуктивності. Вісник Сумського національного аграрного університету. Серія «Тваринництво». 2014. Вип. 2/1 (24). С. 91-97.

30. Хмельничий Л. М., Салогуб А. М., Шевченко А. П., Хмельничий С. Л., Білоног О. О., Бурлаченко К. Ю., Коваль О. М. Мінливість довічної продуктивності корів української чорно-рябої молочної породи залежно від генеалогічних фрормувань. Вісник Сумського національного аграрного університету. Суми, 2012. Вип. 10(20). С. 12-17.

31. Effa K., Hunde D., Shumiye M., Silasie R. H. Analysis of longevity traits and lifetime productivity of crossbred in the Tropical Highlands of Ethiopia. J. Of Cell and Animal Biology. 2013. Vol. 7, No. 11. P. 138-143.

32. Imbayarwo-Chikosi, V. E., Dzama, K., Halimani, T. E., van Wyk, J. B., Maiwashe, A., \& Banga, C. B. Genetic prediction models and heritability estimates for functional longevity in dairy cattle. South African Journal of Animal Science, 2015, 45(2), 106121.

33. Kern, ElisandraLurdes, Cobuci, Jaime Araujo, Costa, CláudioNapolis, McManus, Concepta Margaret, \&BracciniNeto, José. Genetic association between longevity and linear type traits of Holstein cows. Scientia Agricola, 2015, 72(3), 203-209.

34. Zavadilová, L., Štípková M. Genetic correlations between longevity and conformation traits in the Czech Holstein population. Czech J. Anim. Sci., 57, 2012 (3): 125-136.

35. Zavadilová, L., Němcová E., Štípková M., Bouška J. Relationships between longevity and conformation traits in Czech Fleckvieh cows. Czech J. Anim. Sci., 54, 2009 (9): 387-394.

\section{References:}

1. Babik, N. P. and Fedorovych, Ye. I., 2017. Produktyvne dovholittia koriv molochnykh porid za riznoi yikh liniinoi nalezhnosti [Productive longevity of dairy cows with different linear affiliation]. Naukovo-tekhnichnyi biuleten IT NAAN, no. 118, pp. 48-57.

2. Boiko, Yu. M., 2013. Perspektyva selektsii khudoby ukrainskoi buroi molochnoi porody $v$ aspekti liniinoho rozvedennia $z$ vrakhuvanniam svitovykh tendentsii tryvalosti linii u pokolinniakh [Perspective of the cattle selection of Ukrainian Brown dairy breed in the aspect of linear cultivation taking into account world tendencies of lines duration in generations]. Visnyk Sumskoho NAU. Seriia «Tvarynnytstvo», issue 1(22), pp. 20-26.

3. Burkat, V. P. and Ladyka, V. I., 1996. Do pytannia stvorennia molochnoho typu buroi khudoby [On the question of creating a dairy type of Brown cattle]. Improving breeding and productive qualities of the Brown cattle population, Proceedings of the International Conference, Kyiv, June 25-27, 1996. K.: Association "Ukraine", pp. 3-5.

4. Burkat, V. P. and Polupan, Yu. P., 2004. Rozvedennia tvaryn za liniiamy: henezys poniat i metodiv ta suchasnyi selektsiinyi kontekst [Breeding animals by lines: genesis of concepts and methods and modern breeding context]. Kyiv: Ahrarna nauka.

5. Vinnychuk, D. T., Strekozov, N., Ambrampalskyi, F. and Abыlkasыmov D., 1982. Struktura porody velykoi rohatoi khudoby 
[Structure of the breed of cattle]. Visnyk silskohospodarskoi nauky, issue 8, pp. 33-38.

6. Voronina, E., Strekozov, N., Ambrampal'skij, F. and Abylkasymov. D., 2007. Vlijanie variantov podbora korov na ih molochnuju produktivnost' [Influence of cow selection options on their dairy productivity]. Molochnoe i mjasnoe skotovodstvo, no. 4:810.

7. Hanchev, M. M., Boiko, M. F. and Narozhnyi, P. A., 1987. Vyiavlennia poiednuvanosti linii chervonoi stepovoi khudoby pry krosakh [Detection of lines compatibility of red steppe cattle in crosses]. Visnyk silskohospodarskoi nauky, issue 3, pp. 27-28.

8. Honcharenko, I. V., 2004. Tryvalist hospodarskoho vykorystannia molochnykh koriv yak oznaka selektsii [Duration of economic use of dairy cows as a sign of selection]. Visnyk ahrarnoi nauky, issue 6, pp. 33-36.

9. Zubets, M. V., Burkat, V. P., Mel'nik, Yu. F. [et al]. ed. 2007. Zubtsa, M. V. and Burkata, V. P., Genetika, selektsiya i biotekhnologiya v skotovodstve [Genetics, Breeding and Biotechnology in cattle breeding]. Kiev: „БMT”.

10. Kazantseva, E. S., 2015. Pokazateli produktivnogo dolgoletiya korov cherno-pestroy porody v zavisimosti ot lineynoy prinadlezhnosti [Productive longevity indicators of Black-and-White cows depending on the linear affiliation]. Agrarnyy vestnik Urala, no. 6(136), pp. 51-53.

11. Kalchuk, L. A. and Pelekhatyi, M. S., 2001. Zviazok molochnoi produktyvnosti z pokaznykamy vidtvornoi zdatnosti ta hospodarskoho vykorystannia u koriv chorno-riaboi porody [The relationship of milk productivity with indicators of reproductive ability and economic use in Black-and-White cows]. Naukovo-tekhnichnyi biuleten. Kharkiv, issue 80, pp. 64-67.

12. Kononenko, S. I. and Shostak, V. A., 2012. Razvedenie i sovershenstvovanie zhivotnykh novogo regional'nogo tipa krasnogo molochnogo skota [Breeding and improvement of animals of a new regional type of Red dairy cattle]. Rozvedennya i genetika tvarin, issue 46, pp. 24-25.

13. Merkur'eva, E. K., 1977. Geneticheskie osnovy selektsii v skotovodstve [Genetic bases of selection in animal husbandry]. Moskva: Kolos.

14. Moiseev, K. A., Pavlova, T. V. and Kazarovets, N. V., 2012. Vliyanie genotipicheskikh faktorov na prinadlezhnost' khozyaystvennogo ispol'zovaniya i pozhiznennuyu molochnuyu produktivnost' korov v stade RUP "Uchkhoz BGSKhA" [Influence of genotypic factors on the belonging of economic use and lifelong productivity of cows in the herd of RUE "Uchkhoz BGSHA"]. Rozvedennya i henetyka tvaryn, issue 46, pp. 106-109.

15. Pashchenko, S. V., 2010. Povyshenie effektivnosti selektsii molochnogo skota na produktivnoe dolgoletie [Improving the efficiency of dairy cattle breeding for productive longevity]. Niva Povolzh'ya, no. 1, pp. 83-86.

16 Polupan, Yu. P., 2010. Metodyka otsinky selektsiinoi efektyvnosti dovichnoho vykorystannia koriv molochnykh porid [Method of assessing the breeding efficiency of lifetime use cows of dairy breed]. In: Chubynske dedicated to the memory of UAAS Academician Valery Petrovich Burkat, Methodology of scientific research on breeding, genetics and biotechnology in animal husbandry, Proceedings of the International Conference, Chubynske, February 25, 2010. pp. 93-95.

17. Polupan ,Yu., Mashchenko, R., Rozmaritsa, N., Levchenko, L. and Moldovanova, O., 2007. Molochna khudoba Mykolaivshchyny [Dairy cattle of Mykolaivshchyny]. Tvarynnytstvo Ukrainy, no. 6, pp.17-21.

18. Polupan, Yu. P., 2015. Henetychna determinatsiia tryvalosti ta efektyvnosti dovichnoho vykorystannia chorno-riaboi molochnoi khudoby [Genetic determination of the duration and effectiveness of lifetime use of Black-and-White dairy cattle]. Rozvedennia i henetyka tvaryn. Mizhvidomchyi tematychnyi naukovyi zbirnyk, issue 49, pp. 120-133.

19. Popov, N., Ulivanova, G. and Akhmedova, T., 2002. Geneticheskaya i genealogicheskaya odnorodnost' stad chernopestroy porody [Genetic and genealogical homogeneity of herds of Black-and-White breed]. Molochnoe i myasnoe skotovodstvo, issue 4, pp. 22-24.

20. Saksa, E. I. and Borsukova, O. E., 2010. Effektivnost inbridinga pri vyvedenii korov v vysokoproduktivnom stade [Efficiency of inbreeding during the breeding cows in a highly productive herd]. Zootekhniya, issue 2, pp. 2-4.

21. Stavetska, R. V. and Rudyk, I. A., 2010. Dynamika rozvytku linii molochnoi khudoby [Dynamics of dairy cattle lines development]. Zbirnyk naukovykh prats. Seriia "Tekhnolohiia vyrobnytstva i pererobky produktsii tvarynnytstva". Kamianets-Podilskyi, issue 18, pp. 197-200.

22. Khmelnychyi, L. M., 2016. Problema efektyvnoho dovholittia ta dovichnoi produktyvnosti molochnykh koriv v aspekti yikhnoi zalezhnosti vid spadkovykh ta paratypovykh chynnykiv [The problem of effective longevity and lifetime productivity of dairy cows in terms of their dependence on hereditary and paratypic factors]. Visnyk Sumskoho natsionalnoho ahrarnoho universytetu. Seriia «Tvarynnytstvo», issue 7(30), pp. 13-31.

23 Khmelnychyi, L. M. and Vechorka, V. V., 2010. Efektyvnist' vnutrishn'o liniynoho rozvedennya ta poyednuvanosti liniy v selektsiyi holshtyns'koyi khudoby [Efficiency of intra-linear breeding and combining lines in Holstein cattle selection]. Visnyk Sums'koho NAU. Seriya "Tvarynnytstvo", issue 18, pp. 149-153.

24. Khmelnychyi, L. M. and Vechorka, V. V., 2016. Efektyvnist vplyvu henealohichnykh formuvan na pokaznyky dovholittia ta dovichnoi produktyvnosti koriv ukrainskoi chervono-riaboi molochnoi porody [Effectiveness of genealogical formations influencing on the indicators of longevity and lifetime productivity cows of Ukrainian Red-and-White dairy breed]. Visnyk Sumskoho NAU. Seriia «Tvarynnytstvo», issue 1(29), pp. 3-10.

25. Khmelnychyi, L. M. and Salohub, A. M., 2012. Efektyvnist poiednannia henealohichnykh formuvan v selektsii molochnoi khudoby [The effectiveness of the combination of genealogical formations in the selection of dairy cattle]. Zbirnyk naukovykh prats Podilskoho derzh. ahrarno-tekhnichnoho universytetu. Seriia "Tekhnolohiia vyrobnytstva i pererobky produktsii tvarynnytstva". Kamianets-Podilskyi, issue 20, pp. 285-287.

26. Khmelnychyi, L. M., Salohub, A. M., Bondarchuk, V. M. and Loboda, V. P., 2015. Pokaznyky dovichnoi produktyvnosti koriv ukrainskoi chervono-riaboi molochnoi porody zalezhno vid metodiv pidboru [Indicators of lifetime productivity of cows Ukrainian 
Red-and-White dairy breed depending on selection methods]. Tavriiskyi naukovyi visnyk: Naukovyi zhurnal. Kherson, issue 93, pp. 191-196.

27. Khmelnychyi, L. M., Salohub, A. M., Bondarchuk, V. M. and Loboda, V. P., 2015. Tryvalist vykorystannia ta dovichna produktyvnist koriv zalezhno vid metodiv pidboru ta buhaiv-plidnykiv ukrainskoi chervono-riaboi molochnoi porody [Duration of use and cow's lifetime productivity depending on selection methods and sires of Ukrainian Red-and-White dairy breed]. Visnyk Sumskoho natsionalnoho ahrarnoho universytetu. Seriia "Tvarynnytstvo", issue 6(28), pp. 65-70.

28. Khmelnychyi, L. M. and Loboda, V. P., 2014. Otsenka vliyaniya nasledstvennykh faktorov na pokazateli pozhiznennoy produktivnosti korov ukrainskoy krasno-pestroy molochnoy porody [Assessment of hereditary factors influence on lifetime productivity indicators of cows Ukrainian Red-and-White Dairy breed]. Aktual'nye problemy intensivnogo razvitiya zhivotnovodstva: sbornik nauchnykh trudov Belorusskoy gos. sel'khoz. akademii. Gorki : BGSKhA, issue 17(2), pp. 159-165.

29. Khmelnychyi, L. M. and Loboda, V. P., 2014. Udoskonalennia stada z rozvedennia ukrainskoi chervono-riaboi molochnoi porody za pokaznykamy dovichnoi produktyvnosti [Improving the herd for reproduction Ukrainian Red-and-White dairy breed for lifetime productivity indicators]. Visnyk Sumskoho natsionalnoho ahrarnoho universytetu. Seriia: «Tvarynnytstvo», issue 2/1 (24), pp. 91-97.

30. Khmelnychyi, L. M., Salohub, A. M., Shevchenko, A. P., Khmelnychyi, S. L., Bilonoh, O. O., Burlachenko, K. Yu. and Koval, O. M., 2012. Minlyvist dovichnoi produktyvnosti koriv ukrainskoi chorno-riaboi molochnoi porody zalezhno vid henealohichnykh formuvan [Variability lifetime productivity of cows Ukrainian Black-and-White dairy breed based on genealogical groups]. Visnyk Sumskoho natsionalnoho ahrarnoho universytetu. Seriia "Tvarynnytstvo", issue 10(20), pp. 12-17.

31. Effa, K., Hunde D., Shumiye, M. and Silasie, R. H., 2013 Analysis of longevity traits and lifetime productivity of crossbred in the Tropical Highlands of Ethiopia. J. Of Cell and Animal Biology, no. 11, pp. 138-143.

32. Imbayarwo-Chikosi, V. E., Dzama, K., Halimani, T. E., van Wyk, J. B., Maiwashe, A. and Banga, C. B. 2015. Genetic prediction models and heritability estimates for functional longevity in dairy cattle. South African Journal of Animal Science, no. 45(2), pp. 106-121.

33. Kern, Elisandra Lurdes, Cobuci, Jaime Araujo, Costa, Cláudio Napolis, McManus, Concepta Margaret and Braccini Neto, José. 2015. Genetic association between longevity and linear type traits of Holstein cows. Scientia Agricola, no. 72(3), pp. 203-209.

34. Zavadilová, L. and Štípková, M., 2012. Genetic correlations between longevity and conformation traits in the Czech Holstein population. Czech J. Anim. Sci., no. 57(3), pp. 125-136.

35. Zavadilová, L., Němcová E., Štípková M. and Bouška, J., 2009. Relationships between longevity and conformation traits in Czech Fleckvieh cows. Czech J. Anim. Sci., no. 54(9), pp. 387-394.

Khmelnychyi Leontiy Mykhailovych, Doctor of Agricultural Sciences, Professor

Suprun Iryna Oleksandrivna, Ph.D. of Agricultural Sciences, Associate Professor

Bardash Dmytrii Oleksandrovych, PhD student

Sumy National Agrarian University (Sumy, Ukraine)

Lifetime productivity of cows of the Ukrainian Red-and-White dairy breed under various options of selection

The results of researches of cows of the Ukrainian Red-and-White dairy breed were resulted on the traits of duration of economic use and lifetime productivity within the limits of an estimation of genealogical formations. The experimental basis of the research served retrospective selection information of the herd in the enterprise LLC "Mlynivsky Complex" of the Romny branch in the Sumy region. The indicators of the duration and effectiveness of lifetime use were assessed according to the method of Yu. P. Polupan (2010), having recorded information on the dates of birth, first calving and withdrawal for each cow under study. For every lactation were taken into account its duration, the milk yield, the content and output of milk fat for the entire lactation. The hereditary influence of genealogical formations on indicators of duration of economic use and lifetime productivity at intralinear selection and in separate variants of interlinear combinations was studied. According to the results of the offspring evaluation of cows obtained by intra-line selection of five genealogical formations in the controlled herd, was found a reliable influence of lines inheritance on lifetime productivity indicators. Successful and unsuccessful combinations revealed in separate variants of intralinear and interlinear selection testified about necessity of carrying out in stud flocks of a systematic assessment at selection of sires of the corresponding genealogical formations. Repeated use of the most effective options and rejection of unsuccessful ones will help increase the genetic potential of dairy productivity.

Key words: Ukrainian Red-and-White dairy breed, line, lifetime productivity

Дата надходження до редакції: 14.01.2021 р. 